\title{
Study of the binary system fly ash/sugarcane bagasse ash (FA/SCBA) in $\mathrm{SiO}_{2} / \mathrm{K}_{2} \mathrm{O}$ alkali-activated binders
}

\author{
V.N. Castaldelli ${ }^{a}$, J.C.B. Moraes ${ }^{a}$, J.L. Akasaki ${ }^{a}$, J.L.P. Melges ${ }^{a}$, J. Monzó ${ }^{b}$, M.V. Borrachero ${ }^{b}$, L. Soriano ${ }^{b}$, \\ J. Payá ${ }^{\mathrm{b}}$, M.M. Tashima ${ }^{\mathrm{a}, *}$ \\ ${ }^{a}$ UNESP - Univ Estadual Paulista, Campus de Ilha Solteira, São Paulo, Brazil \\ ${ }^{\mathrm{b}}$ ICITECH - Instituto de Ciencia y Tecnología del Hormigón, Universitat Politècnica de València, Valencia, Spain
}

\section{A R T I C L E I N F O}

\section{Article history:}

Received 20 October 2015

Received in revised form 21 January 2016

Accepted 5 February 2016

Available online 11 February 2016

\section{Keywords:}

Alternative binder

Alkaline activation

Waste

Microstructure

Compressive strength

\begin{abstract}
A B S T R A C T
Due environmental problems related to Portland cement consumption, many studies have been performed to diminish its use. One solution is the development of alkali-activated binders, which can decrease $\mathrm{CO}_{2}$ emissions and energy consumption by 70\% when compared to Portland cement production. In addition, an alkali-activated binder presents mechanical properties similar to Portland cement mixtures, which turns into an interesting material in civil construction. Aluminosilicate-based materials are important raw materials to produce the alkali-activated binders. Therefore, two residues are presented as an aluminosilicate source in this study: fly ash (FA) and sugarcane bagasse ash (SCBA). Both residues were obtained from a combustion process to generate energy, the former from coal and the latter from the bagasse of the sugarcane industry. In addition, the alkaline activating solution is an important factor to achieve improved mechanical properties. In this context, this study investigated the influence of four different $\mathrm{SiO}_{2} / \mathrm{K}_{2} \mathrm{O}$ molar ratios $(0,0.36,0.75$ and 1.22) in the activating solution with a constant water content, and three FA/SCBA binder proportions (75/25, 50/50 and 25/75). Microstructural characterization was carried out by X-ray diffraction, Fourier transform infrared spectroscopy, thermogravimetric analysis, scanning electron microscopy, mercury intrusion porosimetry, $\mathrm{pH}$ and electrical conductivity measurements to study the evolution of the reaction process. The compressive strength of mortars was assessed in order to determine the optimum $\mathrm{SiO}_{2} / \mathrm{K}_{2} \mathrm{O}$ molar ratio and $\mathrm{FA} / \mathrm{SCBA}$ ratio. The tests showed that a $\mathrm{SiO}_{2} / \mathrm{K}_{2} \mathrm{O}$ molar ratio of 0.75 and FA/SCBA proportion of $75 / 25$ provided the best mechanical properties.
\end{abstract}

(c) 2016 Elsevier Ltd. All rights reserved.

\section{Introduction}

New materials are being researched worldwide in order to reduce Portland cement consumption. Three main problems are related to the production process of Portland cement: the emission of $\mathrm{CO}_{2}$ (this hydraulic binder is responsible for $5-8 \%$ of global greenhouse gas emissions) [1], energy requirements, and the use of non-renewable materials. In this context, alkali-activated binders (also called geopolymers or inorganic polymers) appear to be an interesting solution in terms of abovementioned problems. An alkali-activated binder is a well-cemented composite obtained through the chemical reaction between an aluminosilicate source with an amorphous structure and a highly concentrated alkaline solution $[2,3]$. The product formed from this reaction is a three-

\footnotetext{
* Corresponding author. Tel.: +55 1837431217.

E-mail address: maumitta@hotmail.com (M.M. Tashima).
}

dimensional tetrahedral structure of aluminate and silicate, where the alkali metal from the solution balances the global negative charge from $\mathrm{Al}^{3+}$ four-fold oxygen coordination [4].

When the production of Portland cement is compared to that of alkali-activated binders, several environmental advantages are highlighted. In terms of gas emissions, the production of one ton of Portland cement clinker releases 0.8 tons of $\mathrm{CO}_{2}$ into the atmosphere [5], whereas some alkali-activated binders emit only 0.184 tons of the greenhouse gas to produce the same amount of binder [6]; this represents a reduction of over 70\% [7]. In terms of energy requirements, alkali-activated binders require $70 \%$ less when compared to Portland cement [8]. The most interesting aspect of alkali-activated binders is that the aluminosilicate sources that have been researched are usually residues [9,10], whereas one ton of Portland cement requires 2.8 tons of nonrenewable raw material (clay and calcium carbonate, among others) [11]. In addition to the environmental advantages, the technological benefits of alkali-activated binders are their high 
compressive strength and durability, which are similar to or better than the characteristics of Portland cement [12].

Several aluminosilicate sources are being studied to produce alkali-activated binders such as fly ash from thermoelectric power plants $[10,13]$, metakaolin [14], spent fluid catalytic cracking catalysts [9], blast-furnace slag [15] and others. In addition, residues from the agroindustry are being researched in alkali-activated binders, such as rice husk ash [16]. Recently, interesting studies have been carried out on binary systems (the presence of two aluminosilicate sources in the mixture as mineral precursors) to improve the mechanical properties of a single-precursor binder; good cementing materials have been produced from these mixtures [17-19]. In this context, this study investigated a binary system consisting of fly ash/sugarcane bagasse ash (FA/SCBA) as an aluminosilicate source for alkali-activated binder production. Both fly ash (FA) and sugarcane bagasse ash (SCBA) are residues of energy generation, the former from coal combustion and the latter from bagasse combustion. Due to the available amount of those residues, civil construction appears to be a suitable choice to valorize these wastes.

Fly ash generation is estimated at over 500 million tons per year [20]. This waste is used to partially replace Portland cement as a pozzolanic material [21], and studies on alkali-activated binders are being carried out [22]. On the other hand, one problem related to sugarcane bagasse ash is its increased production in Brazil. Sugarcane production has expanded by $154 \%$ in the last 15 years in this country, reaching 654 million tons in 2014 [23]. Bagasse represents one quarter of sugarcane mass [24], and $80 \%$ of this by-product is burned in order to generate energy [25]. After the burning process, approximately $2.5 \%$ (by mass) of the bagasse remains as ashes, called sugarcane bagasse ash [26]. Nowadays, this waste is being researched as a pozzolanic material [27], but there are fewer studies on its use in alkali-activated binders [28,29].

In general terms, the alkaline activation of fly ashes requires the use of high waterglass and sodium hydroxide concentrated solutions. Typically, the sodium concentration is in the range of 10-15 $\mathrm{M}$ to obtain suitable compressive strength development [30]. The partial replacement of $\mathrm{FA}$ by $\mathrm{SiO}_{2}$-rich pozzolans could improve the hardening process of fly ashes in the alkaliactivation process [31]. Then, under these conditions, the concentration of the activator could be reduced, with corresponding savings in expensive reagents used for preparing these mixtures. With this purpose, we present here the role of SCBA in FA alkaliactivated systems.

In this paper, alkali-activated binders were obtained from a binary system of FA/SCBA as the aluminosilicate source, activated by a solution of potassium hydroxide and potassium silicate. This study was carried out in two sections: in the first part, the influence of the $\mathrm{SiO}_{2} / \mathrm{K}_{2} \mathrm{O}$ molar ratio to select the optimum solution was assessed, and in the second part, different proportions of FA/SCBA were assessed in order to achieve the best mechanical performance. Evolution of the reaction process was assessed in pastes by Fourier transformed infrared spectroscopy (FTIR), thermogravimetric analysis (TGA), X-ray diffraction (XRD), pH/electrical conductivity measurements and mercury intrusion porosimetry (MIP). The compressive strength test for mortars was performed in order to select the optimum $\mathrm{SiO}_{2} / \mathrm{K}_{2} \mathrm{O}$ molar ratio in the solution and the optimum FA/SCBA proportion in the binder.

\section{Materials and methods}

\subsection{Materials}

Fly ash (FA) was supplied by Infraestructuras Balalva, Spain. This ash was ground in an industrial ball mill for $10 \mathrm{~h}$ in order to enhance its reactivity. Sugarcane bagasse ash (SCBA) was taken from a settling lagoon at Destilaria Generalco S/A, close to General Salgado, Brazil. In this factory, the bagasse was burnt to obtain energy, and the ash generated was collected using a scrubber. The resulting suspension was mixed with water from sugarcane washing, and afterwards it was poured into the lagoon. The settled solids were retrieved from the lagoon. Afterwards, the sugarcane bagasse ash was dried at $105^{\circ} \mathrm{C}$ and milled for $20 \mathrm{~min}$ in a ball mill in order to increase its reactivity [28]. This original ash (non-calcined ash), in a first approach, was tested for preparing geopolymeric mixtures. However, some problems in setting and hardening were observed, since the residue presents a high amount of organic matter [28]. Thus, in order to remove it, the original ash was calcined at $650{ }^{\circ} \mathrm{C}$ for $2 \mathrm{~h}$. Then, the obtained calcined ash was used for geopolymeric mixtures (named SCBA for the rest of the manuscript). The chemical compositions of FA and SCBA are shown in Table 1 . The crystalline compounds present in FA were mainly quartz $\left(\mathrm{SiO}_{2}\right.$, PDF card\# 331161) and mullite $\left(3 \mathrm{Al}_{2} \mathrm{O}_{3} .2 \mathrm{SiO}_{2}\right.$, PDF card\# 150776$)$, whereas for SCBA there were mainly quartz and calcite $\left(\mathrm{CaCO}_{3}\right.$, PDF card\# 050586). The particle size distribution and derivative granulometric curves of FA and SCBA are shown in Fig. 1 . The mean particle diameter $\left(D_{\text {mean }}\right)$ and ninety percent passing size $\left(D_{90}\right)$ for FA were 9.11 and $40.18 \mu \mathrm{m}$, respectively, whereas the SCBA values for $D_{\text {mean }}$ and $D_{90}$ were 18.47 and $61.31 \mu \mathrm{m}$, respectively. SEM images of FA and SCBA particles are shown in Fig. 2. SCBA particles (Fig. 2a and b) had an irregular shape, but some particles showed a specific shape (prismatic, see Fig. 2a) [32]. Fly ash (Fig. 2c and d) presented as spherical particles, although some irregular particles were produced during the milling process.

In the preparation of the alkaline solutions, potassium hydroxide and potassium silicate were used as alkaline reagents. Potassium hydroxide pellets (85\% purity) were supplied by Panreac SA, and the potassium silicate solution (waterglass, $8.5 \mathrm{wt} \% \mathrm{~K}_{2} \mathrm{O}$, $21.5 \mathrm{wt} \% \mathrm{SiO}_{2}$ and $70.0 \mathrm{wt} \% \mathrm{H}_{2} \mathrm{O}$ ) was supplied by Kremer. For mortar specimens, siliceous sand with a fineness modulus of 4.1 and a specific gravity of $2680 \mathrm{~kg} / \mathrm{m}^{3}$ was used.

\subsection{Preparation of alkali-activated binders}

Studies on alkali-activated binders were performed in two sections. In the first part of the study (Section 1), the $\mathrm{SiO}_{2} / \mathrm{K}_{2} \mathrm{O}$ molar ratio in the solution was varied in order to identify the optimum value, and the FA/SCBA proportion was held constant at 50/50 by mass. In the second part of the study (Section 2), only this optimized solution was used, and the FA/SCBA proportion was varied in order to achieve the best mechanical properties. In both studies, tests were carried out on pastes and mortars. The $\mathrm{H}_{2} \mathrm{O} / \mathrm{K}_{2} \mathrm{O}$ molar ratio was held constant at 13.89 and the water/binder (as the sum of FA and SCBA) ratio was 0.45 . For mortars, sand was used at a sand/binder ratio of $3 / 1$ by mass.

Four solutions were assessed in the first section of the study, where the $\mathrm{SiO}_{2} / \mathrm{K}_{2} \mathrm{O}$ molar ratios evaluated were $0(\mathrm{~S} 1), 0.35$ (S2), 0.75 (S3) and 1.22 (S4). The FA/SCBA proportion was held constant at a ratio of $50 / 50$. The optimum $\mathrm{SiO}_{2} / \mathrm{K}_{2} \mathrm{O}$ molar ratio selected for the second section was $0.75(\mathrm{~S} 3)$. In the subsequent part of the study, the FA/SCBA proportions assessed were 75/25, 50/50 and $25 / 75$. Table 2 summarizes the alkali-activated binders studied in each section. The specimens were named according to the solution used (S1, S2, S3 and S3) and the FA/SCBA proportion (75/25, 50/50 and 25/75).

In the preparation of paste and mortar specimens, the alkaline activators (potassium hydroxide and potassium silicate) were dissolved in the water and the binder (FA/SCBA) was added to the solution, then allowed to reach room temperature. For mortars, the binder was mixed with the alkaline solution for 4 min and then 
Table 1

Chemical composition of FA and SCBA in percentage.

\begin{tabular}{|c|c|c|c|c|c|c|c|c|c|c|c|c|}
\hline Oxide (\%) & $\mathrm{SiO}_{2}$ & $\mathrm{Al}_{2} \mathrm{O}_{3}$ & $\mathrm{Fe}_{2} \mathrm{O}_{3}$ & $\mathrm{CaO}$ & $\mathrm{MgO}$ & $\mathrm{Na}_{2} \mathrm{O}$ & $\mathrm{K}_{2} \mathrm{O}$ & $\mathrm{SO}_{3}$ & $\mathrm{TiO}_{2}$ & $\mathrm{MnO}$ & $\mathrm{Cl}$ & LOI \\
\hline FA & 51.83 & 26.04 & 11.84 & 3.03 & 1.05 & 0.46 & 2.67 & 0.70 & 0.87 & $<0.10$ & $<0.10$ & 1.41 \\
\hline SCBA & 43.34 & 10.45 & 8.31 & 22.16 & 1.48 & 0.19 & 2.18 & 1.08 & 2.88 & 0.14 & 0.19 & 7.61 \\
\hline
\end{tabular}

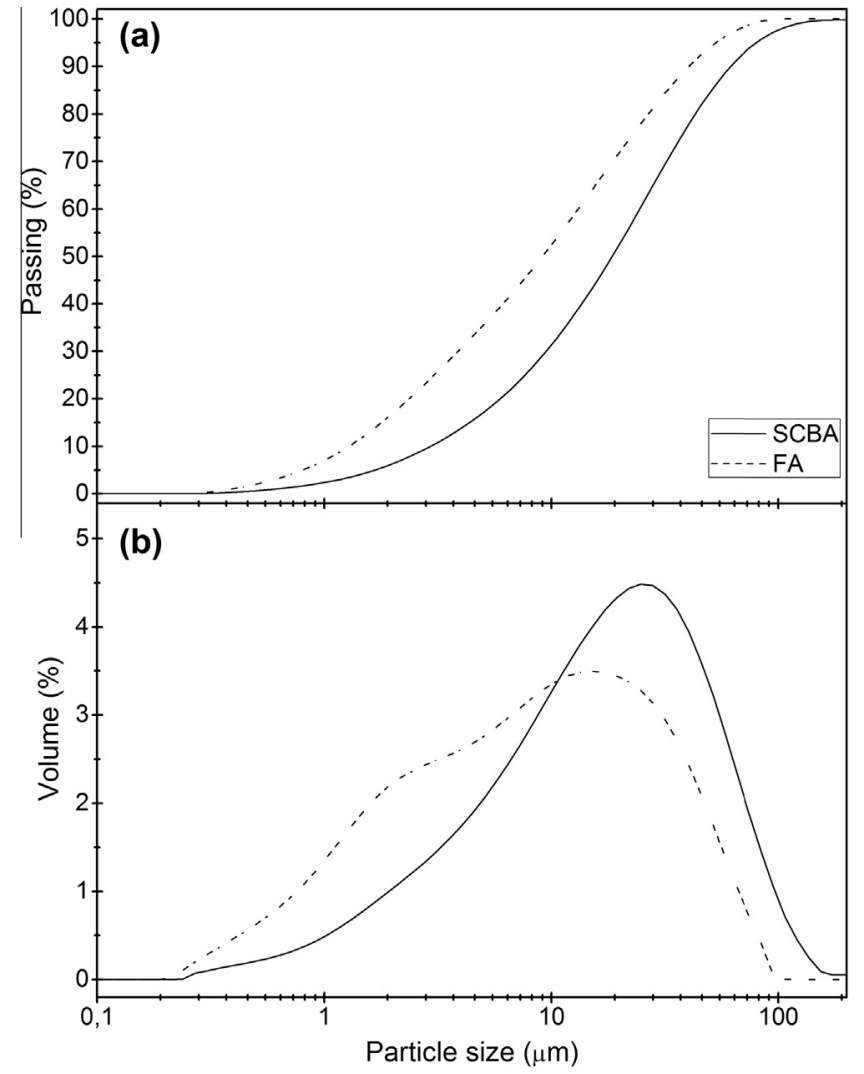

Fig. 1. Particle size distribution of FA and SCBA: (a) cumulative curve and (b) derivative curve.

sand was added to the paste, followed by mixing for more $3 \mathrm{~min}$. The fresh mortar was vibrated for $1 \mathrm{~min}$ in a prismatic mold $\left(40 \times 40 \times 160 \mathrm{~mm}^{3}\right)$ and sealed with plastic film. Afterwards, some molds were stored at room temperature $\left(20^{\circ} \mathrm{C}\right)$ and others in a thermal bath $\left(65^{\circ} \mathrm{C}\right)$ at a relative humidity $(\mathrm{RH})$ higher than $95 \%$. Specimens were demolded after $24 \mathrm{~h}$ at room temperature and after $4 \mathrm{~h}$ for thermal bath, then returned to their respective curing conditions until testing. The pastes were cured under the same curing conditions as the mortars.

\subsection{Tests carried out on alkali-activated pastes and mortars}

Pastes were used in order to assess the reaction evolution of alkali-activated binders. The following experimental techniques were used: thermogravimetric analysis (TGA), X-ray diffraction (XRD) and $\mathrm{pH} /$ electrical conductivity measurements (in both Sections 1 and 2), Fourier transform infrared spectroscopy (FTIR) and mercury intrusion porosimetry (MIP) (only in Section 2).

TGA was carried out in a Mettler-Toledo TGA 85 thermobalance, where the DTG curve was obtained from 35 to $550{ }^{\circ} \mathrm{C}$ at a heating rate of $10^{\circ} \mathrm{C} / \mathrm{min}$ under an $\mathrm{N}_{2}$ atmosphere $(75 \mathrm{~mL} / \mathrm{min}$ gas flow). Aluminum sealed crucibles $(100 \mu \mathrm{L})$ with a pinholed lid were used. X-ray diffraction studies were assessed using a Bruker AXS D8 Advance diffractometer in the $2 \theta$ range of $5-70^{\circ}$, using $\mathrm{Cu}-\mathrm{K} \alpha$ radiation and an Ni filter, with a voltage of $40 \mathrm{kV}$ and current intensity of $20 \mathrm{~mA}$. Electrical conductivity and $\mathrm{pH}$ measurements were performed as proposed by Tashima et al. [9] using a Crison microCM2201 conductimeter and Crison micropH2001 pH-meter. The procedure consists of mixing $1 \mathrm{~g}$ of crushed paste of the alkali-activated binder in $10 \mathrm{~g}$ of deionized water and stirring the mixture for $10 \mathrm{~min}$ to dissolve the free ions. In this test, the $\mathrm{pH}$ and electrical conductivity should decrease as the alkaliactivation reaction evolves due the reduction of free ions in the mixture. FTIR was performed in the wavenumber range of 400 and $4000 \mathrm{~cm}^{-1}$ using a Bruker TENSOR 27 FTIR apparatus. MIP was performed using an AutoPore IV 9500 (Micromeritics Instrument Corporation), with an intrusion pressure of $14 \mathrm{kPa}$ to 227.4 MPa, which are equivalent to measuring pores in the range of $91.26 \mu \mathrm{m}$ to $5.5 \mathrm{~nm}$. For the studies in Section 1, pastes were studied after 3 and 7 days of curing at $65^{\circ} \mathrm{C}$, whereas for Section 2 , samples were assessed after 7, 28, 90 and 270 days of curing at room temperature, and after 3 and 7 days of curing at $65^{\circ} \mathrm{C}$.

Mortar specimens were evaluated by compressive strength tests following the procedures from UNE-EN 196-1 [33] and by the MIP test. The compressive strength value was an average of five specimens, since the sixth was used in the MIP test. Tests were performed after 3 and 7 days of curing at $65^{\circ} \mathrm{C}$ (for both Sections 1 and 2), and after 7, 28 and 270 days of curing at room temperature (only for Section 2).

\section{Results and discussion}

The tested fly ash could not be properly activated using typical alkaline solutions (e.g. $\mathrm{H}_{2} \mathrm{O} / \mathrm{M}_{2} \mathrm{O}$ molar ratio of 11.11-13.89, mixes of $\mathrm{MOH}$ and waterglass, $\mathrm{M}=\mathrm{Na}, \mathrm{K}$ ), either at room temperature or at $65{ }^{\circ} \mathrm{C}$ after $24 \mathrm{~h}$ of curing. The partial replacement of FA by noncalcined SCBA (original ash) did not allow for hardening under these conditions. Only following the removal of the organic matter in SCBA by calcining it at $650^{\circ} \mathrm{C}$ were the FA/SCBA mixtures able to harden at room temperature. Certainly, the organic compounds present in the as-received SCBA delayed the formation of gels in the alkaline activation reaction. This is the reason why, in this report, calcined SCBA was used as the raw material.

\subsection{Results for Section 1: determination of the optimum $\mathrm{SiO}_{2} / \mathrm{K}_{2} \mathrm{O}$ ratio}

Fig. 3 shows the results of the compressive strength tests on mortars after 3 and 7 days of curing at $65^{\circ} \mathrm{C}$. All alkali-activated mortars showed an increase in compressive strength from 3 to 7 days of curing. It was noted that $\$ 1-50 / 50$ and S2-50/50 showed significantly lower values compared to S3-50/50 and S4-50/50 for both curing ages. After 3 days of curing, mortars with a low $\mathrm{SiO}_{2} / \mathrm{K}_{2} \mathrm{O}$ ratio achieved strength values below $10 \mathrm{MPa}$ $(8.0 \pm 0.3 \mathrm{MPa}$ for S1-50/50, and $3.3 \pm 0.3 \mathrm{MPa}$ for S2-50/50), whereas higher strength values were obtained with increasing the $\mathrm{SiO}_{2} / \mathrm{K}_{2} \mathrm{O}$ ratio, to above $25 \mathrm{MPa}(27.0 \pm 3.2 \mathrm{MPa}$ for $\mathrm{S} 3-50 / 50$ and $30.8 \pm 0.9 \mathrm{MPa}$ for S4-50/50). This fact reveals the importance of the chemical composition of the alkaline activator in the development of compressive strength $[9,34,35]$. After 7 days of curing, the compressive strength of mortars increased slightly; thus, mortars activated with potassium hydroxide (S1) displayed increased strength to $10.8 \pm 1.2 \mathrm{MPa}$. The presence of $\mathrm{SiO}_{2}$ in the alkaline activator produced an increase in the compressive strength of 

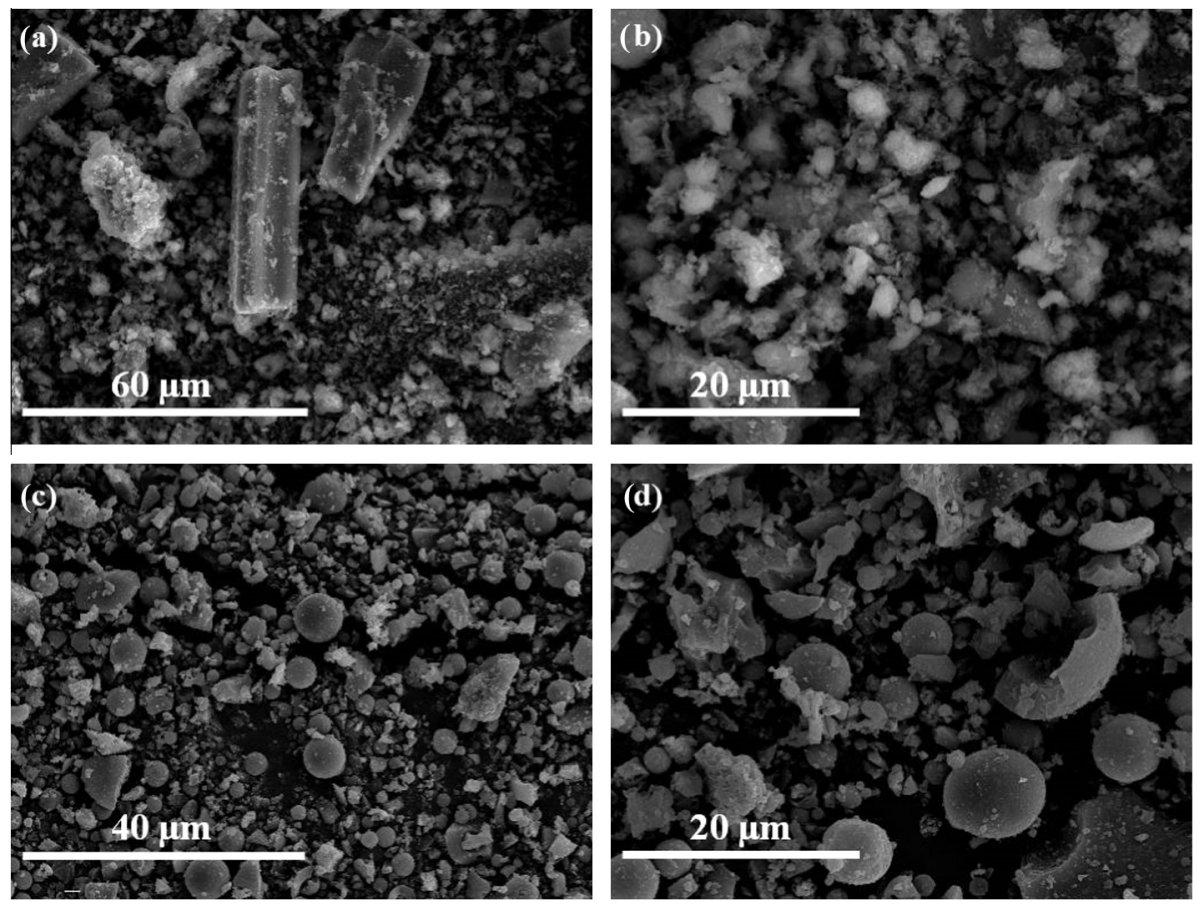

Fig. 2. SEM images of SCBA (a and b) and FA (c and d).

Table 2

Nomenclature of the prepared mixtures for pastes and mortars.

\begin{tabular}{|c|c|c|c|}
\hline $\begin{array}{l}\text { Alkali-activated binder } \\
\text { mixtures }\end{array}$ & $\begin{array}{l}\mathrm{SiO}_{2} / \mathrm{K}_{2} \mathrm{O} \\
\text { (molar ratio) }\end{array}$ & $\begin{array}{l}\mathrm{FA} / \mathrm{SCBA} \text { (mass } \\
\text { ratio) }\end{array}$ & $\begin{array}{l}\text { Curing } \\
\text { temperature }\end{array}$ \\
\hline \multicolumn{4}{|l|}{ Section 1} \\
\hline$S 1-50 / 50$ & 0.00 & $50 / 50$ & $65^{\circ} \mathrm{C}$ \\
\hline $\mathrm{S} 2-50 / 50$ & 0.38 & $50 / 50$ & $65^{\circ} \mathrm{C}$ \\
\hline S3-50/50 & 0.75 & $50 / 50$ & $65^{\circ} \mathrm{C}$ \\
\hline S4-50/50 & 1.22 & $50 / 50$ & $65^{\circ} \mathrm{C}$ \\
\hline \multicolumn{4}{|l|}{ Section 2} \\
\hline S3-75/25 & 0.75 & $75 / 25$ & 20 and $65^{\circ} \mathrm{C}$ \\
\hline S3-50/50 & 0.75 & $50 / 50$ & 20 and $65^{\circ} \mathrm{C}$ \\
\hline S3-25/75 & 0.75 & $25 / 75$ & 20 and $65^{\circ} \mathrm{C}$ \\
\hline
\end{tabular}

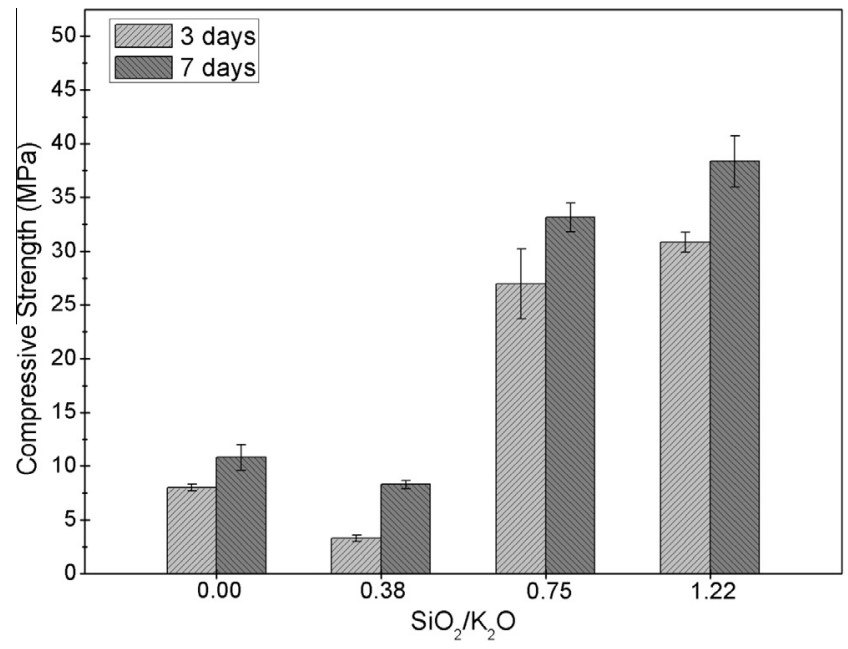

Fig. 3. Compressive strength of alkali-activated binders after 3 and 7 days of curing at $65{ }^{\circ} \mathrm{C}$ using different alkaline activating solutions and a 50/50 FA/SCBA ratio. between 5 and $7 \mathrm{MPa}(8.3 \pm 0.4 \mathrm{MPa}$ for $\mathrm{S} 2-50 / 50,33.1 \pm 1.3 \mathrm{MPa}$ for S3-50/50 and 38.4 $\pm 2.4 \mathrm{MPa}$ for S4-50/50). No decay in compressive strength was observed following thermal treatment, suggesting that these cement products are stable (probably no zeolitic structure was formed). Certainly, the presence of potassium cations as the activating agent favored the stability of the gel structure [36].

Table 3 summarizes the mass losses assessed by TGA studies on pastes after 3 and 7 days of curing at $65^{\circ} \mathrm{C}$; the DTG curves are shown in Fig. 4. Mass loss between 100 and $200{ }^{\circ} \mathrm{C}$ is related to the dehydration of alkali-activated products [37]. First, it was noted that S2-50/50 presented the lowest mass loss for both curing ages; this behavior agrees with the differences found in compressive strength development. The alkali-activated mixture S1-50/50 presented lower mass loss compared to S3-50/50 and S4-50/50 after 3 days of curing, but the results after 7 days of curing showed similar values for the three mixtures. Despite similar mass losses for S1-50/50, S3-50/50 and S4-50/50, it was noted that the temperature peaks in the DTG curves were very different (see Table 3 and Fig. 4). Thus, S1-50/50 showed the highest temperature peak ( $150{ }^{\circ} \mathrm{C}$ after 3 days of curing and $144^{\circ} \mathrm{C}$ for 7 days), and an additional shoulder appeared at higher temperature $\left(180\right.$ to $\left.200{ }^{\circ} \mathrm{C}\right)$. The gel characterized for the S3-50/50 and S4-50/50 mixtures was different because the temperature peak moved to lower values, i.e. $134^{\circ} \mathrm{C}$ and $137^{\circ} \mathrm{C}$, respectively, after 3 days, while both presented a peak at $136^{\circ} \mathrm{C}$ after 7 days of curing.

Only the mixtures S1-50/50 and S2-50/50 increased their mass loss from 3 to 7 days of curing, whereas S3-50/50 and S4-50/50 practically remained constant. For these last two mixtures, no direct relationship between mass change and strength development was found. This means that the polymerization of $\mathrm{SiO}_{4}$ and $\mathrm{AlO}_{4}$ tetrahedra that enhanced mechanical properties did not promote an increase in the total combined water.

The results of $\mathrm{pH}$ and electrical conductivity of pastes after 3 and 7 days of curing at $65{ }^{\circ} \mathrm{C}$ are shown in Table 3 . In the beginning of the alkali-activated reaction, ions are present from the alkaline activator $\left(\mathrm{OH}^{-}\right.$and $\left.\mathrm{K}^{+}\right)$and from the dissolution of the 
Table 3

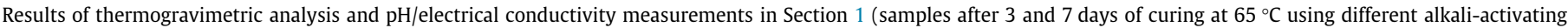
solutions and a 50/50 FA/SCBA ratio).

\begin{tabular}{|c|c|c|c|c|c|c|c|c|}
\hline \multirow[t]{3}{*}{ Mixture } & \multicolumn{4}{|c|}{ TGA data } & \multirow{2}{*}{\multicolumn{2}{|c|}{$\mathrm{pH}$}} & \multirow{2}{*}{\multicolumn{2}{|c|}{$\begin{array}{l}\text { Electrical conductivity } \\
(\mu \mathrm{S} / \mathrm{cm})\end{array}$}} \\
\hline & \multicolumn{2}{|c|}{ Total mass loss (\%) } & \multicolumn{2}{|c|}{ Peak temperature $\left({ }^{\circ} \mathrm{C}\right)$} & & & & \\
\hline & 3 days & 7 days & 3 days & 7 days & 3 days & 7 days & 3 days & 7 days \\
\hline $\mathrm{S} 1-50 / 50$ & 8.40 & 10.67 & 150 & 144 & 12.79 & 12.71 & 17.69 & 15.08 \\
\hline S2-50/50 & 7.71 & 8.90 & 154 & 146 & 12.74 & 12.66 & 16.87 & 12.85 \\
\hline S3-50/50 & 10.45 & 10.44 & 137 & 136 & 12.54 & 12.51 & 13.06 & 11.95 \\
\hline S4-50/50 & 11.38 & 10.38 & 134 & 136 & 12.43 & 12.39 & 11.6 & 10.33 \\
\hline
\end{tabular}

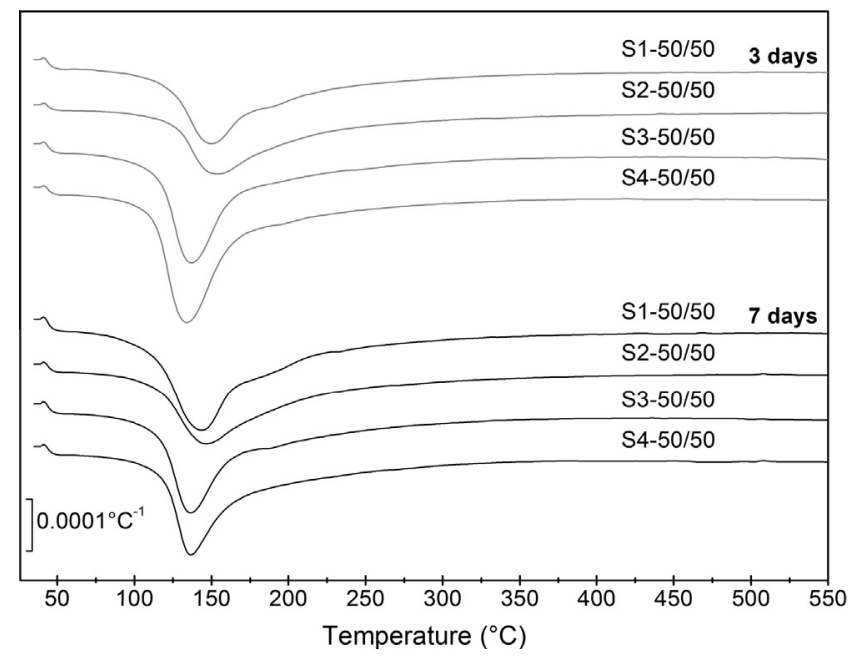

Fig. 4. DTG curves of alkali-activated binders after 3 and 7 days of curing at $65{ }^{\circ} \mathrm{C}$ using different alkaline activating solutions and a 50/50 FA/SCBA ratio.

aluminosilicate sources $\left(\mathrm{SiO}_{4}\right.$ tetrahedral ions and $\mathrm{AlO}_{4}$ tetrahedral ions). As the alkali-activated reaction evolves, a decrease in ions occurs in the solution due to gel formation and, consequently, a decrease in the $\mathrm{pH}$ (less concentration of $\mathrm{OH}^{-}$) and electrical conductivity (much lower quantity of ions) is observed. For all alkaliactivated mixtures, both $\mathrm{pH}$ and electrical conductivity decreased with the curing time. In addition, a higher $\mathrm{SiO}_{2} / \mathrm{K}_{2} \mathrm{O}$ molar ratio was associated with lower $\mathrm{pH}$ and electrical conductivity values. The alkali-activated mixtures $\mathrm{S} 1-50 / 50$ and S2-50/50 presented more significant decreases from 3 to 7 days of curing compared to S3-50/50 and S4-50/50. These results are similar to those from TGA studies.

In general terms, related to $\mathrm{pH}$ and electrical conductivity studies, pastes with lower values in these tests presented higher compressive strength as mortars. It is likely that the increase in polymerization produced more ion linking and, consequently, strength development was enhanced.

The XRD patterns of pastes after 7 days of curing at $65^{\circ} \mathrm{C}$ are shown in Fig. 5 together with those of the raw materials, FA and SCBA. In all pastes, a deviation of the baseline between $23^{\circ}$ and $35^{\circ}$ was observed, which represents the amorphous phase of the alkali-activated reaction products. These products were amorphous, and the peaks shown in the XRD patterns were attributed to the raw materials. The crystalline phases of the raw materials, FA and SCBA, present in the pastes include quartz, calcite, gypsum ( $\mathrm{CaSO}_{4} \cdot 2 \mathrm{H}_{2} \mathrm{O}$, PDF card\# 036-0432), mullite, hematite $\left(\mathrm{Fe}_{2} \mathrm{O}_{3}\right.$, PDF card\# 33-0664) and magnetite ( $\mathrm{Fe}_{3} \mathrm{O}_{4}$, PDF card\# 19-0629). No zeolites were formed in the activation process using the tested solutions. In the raw materials, the amorphous phase was identified as a baseline deviation between $15^{\circ}$ and $30^{\circ}$. These amorphous phases were transformed during the alkaline activation reaction, and the gels formed showed a shift of the baseline deviation

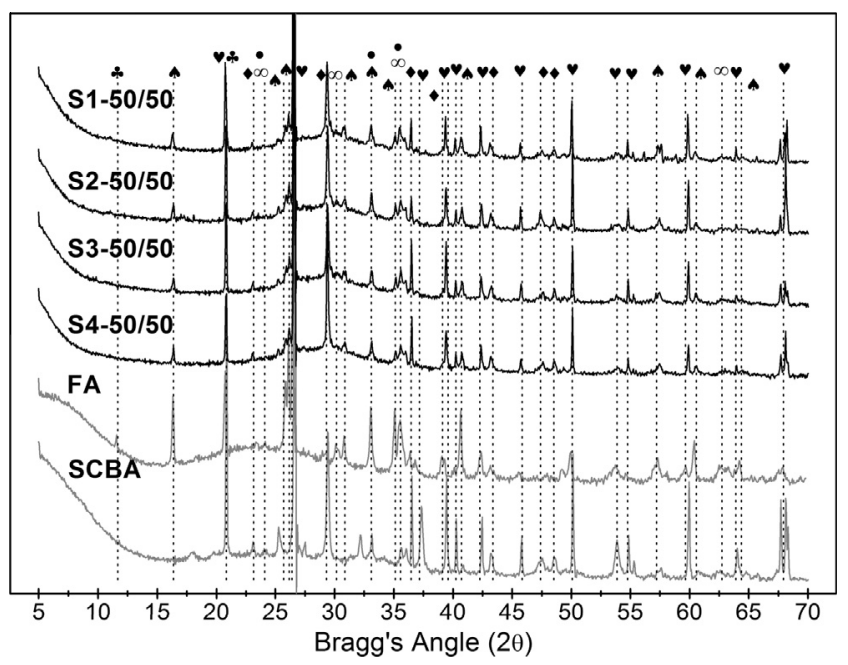

Fig. 5. XRD patterns of alkali-activated binders after 7 days of curing at $65{ }^{\circ} \mathrm{C}$ using different alkali-activating solutions and 50/50 FA/SCBA ratio (key: $\bullet$ : quartz; $\bullet$ : calcite; $\boldsymbol{中}$ : gypsum; $\boldsymbol{\phi}$ : mullite; $\bullet$ : hematite; $\infty$ : magnetite).

between $23^{\circ}$ and $35^{\circ}$. This behavior is typical for the transformation of an amorphous raw material into a gel during the activation process $[9,38]$.

In summary, based on this analysis of the behavior of alkaliactivated mixtures with different $\mathrm{SiO}_{2} / \mathrm{K}_{2} \mathrm{O}$ molar ratio, the solution $\mathrm{S} 3\left(\mathrm{SiO}_{2} / \mathrm{K}_{2} \mathrm{O}=0.75\right)$ was selected for tests in Section 2. This solution presented better mechanical properties compared to S1 and S2, whereas, when compared to S4, it presented similar compressive strength with less consumption of potassium silicate. It is important to note that this type of reagent, alkali silicate, is the most expensive component of the mixture and it has an important carbon footprint [39]. Therefore, it has been demonstrated that mixing both ashes, FA and SCBA, allows for producing good binding materials. We thus decided to develop FA/SCBA systems with appropriate mechanical properties at room temperature.

\subsection{Results for Section 2: determination of the optimum FA/SCBA proportion}

In this section, different $\mathrm{FA} / \mathrm{SCBA}$ proportions were assessed: $75 / 25,50 / 50$ and $25 / 75$. These mixtures were activated by using solution $\mathrm{S} 3$, with a $\mathrm{SiO}_{2} / \mathrm{K}_{2} \mathrm{O}$ molar ratio of 0.75 , cured at room temperature and $65^{\circ} \mathrm{C}$.

The FTIR spectra of pastes after 3 and 7 days of curing at $65^{\circ} \mathrm{C}$ are shown in Fig. 6. The fly ash main vibrations bands were 1070 , and $459 \mathrm{~cm}^{-1}(\mathrm{Si}-\mathrm{O})$, and $551 \mathrm{~cm}^{-1}(\mathrm{Al}-\mathrm{O})$, whereas for SCBA they were 1056, 780 and $490 \mathrm{~cm}^{-1}(\mathrm{Si}-\mathrm{O})$, and 1441 and $872 \mathrm{~cm}^{-1}$ (O-C-O) [37,40-41]. In the pastes, for all curing ages, the following vibration bands were observed: $\approx 1006$ and $459 \mathrm{~cm}^{-1}(\mathrm{Si}-\mathrm{O})$, and 1441 and $872 \mathrm{~cm}^{-1}(\mathrm{O}-\mathrm{C}-\mathrm{O})$. The vibration band at $1006 \mathrm{~cm}^{-1}$ 
was attributed to the formed product due to the alkali-activated reaction, since this band did not appear in the FA and SCBA spectra. In addition, this vibration band did not change between 3 and 7 days of curing for the same mixture, indicating that there was no significant change in the nature of the gel between these curing ages. The vibration band at $459 \mathrm{~cm}^{-1}$ was maintained at all curing ages, indicating that this vibration can be attributed to the quartz in SCBA and FA. The vibration bands at 1441 and $872 \mathrm{~cm}^{-1}$ are related to the presence of carbonates in SCBA.

The mass losses from the TGA studies on pastes are summarized in Table 4 for curing at $65^{\circ} \mathrm{C}$ and Table 5 for curing at room temperature, whereas the DTG curves are shown in Fig. 7. For pastes cured at a temperature of $65^{\circ} \mathrm{C}$, Table 4 shows that the mass loss was practically maintained from 3 to 7 days of curing, confirmed by the DTG curves in Fig. 7a. In addition, the temperature peaks in the DTG curves did not shift with the curing age. However, interestingly, there was an important change in the temperature distribution of the mass loss. Thus, the mass losses in the range $35-200{ }^{\circ} \mathrm{C}\left(L_{35-200}\right)$ and $200-550{ }^{\circ} \mathrm{C}\left(L_{200-550}\right)$ were compared, and a $\tau$ ratio is proposed, which was calculated using these mass losses as follows: $\tau=L_{35-200} / L_{200-550}$. These $\tau$ values revealed that there was a significant variation in the nature of the bonded water in the gels with curing time [42]. Therefore, for 3 days curing time at $65^{\circ} \mathrm{C}, \tau$ values were in the range of $1.72-2.31$. For 7 days of curing time, a reduction in the $\tau$ values was observed for all pastes (1.44-1.86 range). Although the total combined water did not vary with curing time, the $\tau$ values decreased. It can be assumed that the mass loss in the $35-200{ }^{\circ} \mathrm{C}$ range can be attributed to the evaporation of water molecules bonded to the gel structure. These molecules are bonded through molecular interaction or hydrogen bond to $\mathrm{Si}(\mathrm{Al})-\mathrm{O}-\mathrm{K}^{+}$network and, consequently, lower energy (low temperature) is required for debonding. However, an important part of mass loss took place at temperatures higher than $200^{\circ} \mathrm{C}$. In this case, water molecules were generated by the condensation of $\mathrm{OH}$ groups in silanol $(\mathrm{Si}-\mathrm{O}-\mathrm{H})$ and aluminol $(\mathrm{Al}-\mathrm{O}-\mathrm{H})$ units. This reaction takes place at high temperatures because the bonds involved are covalent. The reduction in the $\tau$ value confirms the alkaline activation reaction progress and, consequently, more products are formed.

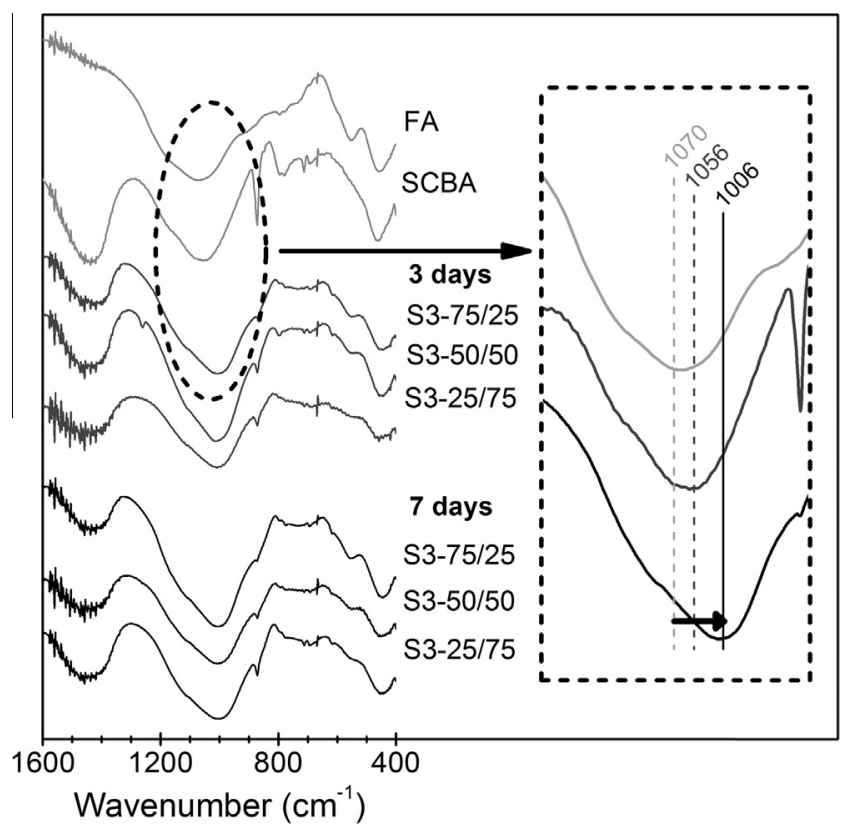

Fig. 6. FTIR spectra of alkali-activated binders after 3 and 7 days of curing at $65^{\circ} \mathrm{C}$ : mixtures prepared with different FA/SCBA ratios.
Table 4

TGA results from Section 2 studies after 3 and 7 days of curing at $65^{\circ} \mathrm{C}$ for pastes prepared with different FA/SCBA ratios.

\begin{tabular}{|c|c|c|c|c|c|c|}
\hline \multirow[t]{2}{*}{ Mixture } & \multicolumn{2}{|c|}{$\begin{array}{l}\text { Total mass loss } \\
(\%)\end{array}$} & \multicolumn{2}{|c|}{$\begin{array}{l}\text { Peak temperature } \\
\left({ }^{\circ} \mathrm{C}\right)\end{array}$} & \multicolumn{2}{|c|}{$\tau\left(L_{35-200} / L_{200-550}\right)^{\mathrm{a}}$} \\
\hline & 3 days & 7 days & 3 days & 7 days & 3 days & 7 days \\
\hline S3-75/25 & 11.82 & 12.22 & 138 & 135 & 2.12 & 1.86 \\
\hline S3-50/50 & 10.45 & 10.44 & 137 & 136 & 1.72 & 1.44 \\
\hline S3-25/75 & 11.92 & 11.05 & 134 & 134 & 2.31 & 1.79 \\
\hline
\end{tabular}

a $L_{35-200}$ is the mass loss in the temperature range of $35-200{ }^{\circ} \mathrm{C}$, whereas $L_{200-550}$ is the mass loss in the range of $200-550^{\circ} \mathrm{C}$.

In general terms, a similar trend was observed for samples cured at room temperature. Interestingly, after 7 days of curing time at room temperature, the $\tau$ value was the range of 2.674.05 , which means that the combined water mainly consisted of water molecules bonded through molecular bonding. For the longest curing time, at 270 days, the $\tau$ values were significantly lower, in the range of 0.57-0.59, meaning that most water molecules released by heating were produced from the condensation of silanol and aluminol units. In this case, a large shift in the temperature peak was observed for all tested pastes when the curing time was increased.

The XRD patterns of pastes are shown in Figs. 8 and 9 for curing at $65{ }^{\circ} \mathrm{C}$ and room temperature, respectively. For all X-ray diffractograms, a deviation in the baseline was observed between $23^{\circ}$ and $35^{\circ}$ due to the amorphous phase related to the alkali-activated products. A similar halo was described in Section 1, and the influence of the FA/SCBA ratio and curing temperature was negligible. In addition, the crystalline phases of FA and SCBA were maintained in the XRD pattern of $S 3$ pastes. Once again, no zeolites from the alkali-activated reaction were observed in these patterns.

The results of $\mathrm{pH}$ and electrical conductivity studies are shown in Fig. 10a and $\mathrm{c}$ for pastes cured at $65^{\circ} \mathrm{C}$, and in Fig. $10 \mathrm{~b}$ and $\mathrm{d}$ for pastes cured at room temperature. It was noted that, for all mixtures, the $\mathrm{pH}$ and electrical conductivity decreased with curing time. This result was expected, since there was a lower concentration of $\mathrm{OH}^{-}$and other ions in the pore solution due to the alkali activation process. For the pastes cured at $65^{\circ} \mathrm{C}, \mathrm{S} 3-75 / 25$ showed the lowest value for both $\mathrm{pH}$ and electrical conductivity after 7 days of curing. From 7 to 28 days of curing at room temperature, the $\mathrm{pH}$ presented a slight decrease, although the pastes presented a reduction in the $\mathrm{OH}^{-}$concentration of $59-75 \%$. In the same way, the electrical conductivity of pastes also decreased by $43 \%$. The decreases in $\mathrm{pH}$ and electrical conductivity from 7 to 28 days were greater for the S3-25/75 mixture; this behavior suggests that the reaction early in the aging progressed more quickly in the presence of a high amount of SCBA. From 28 to 270 days, the decrease in $\mathrm{pH}$ values was considerable, reaching around 11 . This means that the $\mathrm{OH}^{-}$concentration of pastes was very low $\left(96 \%\right.$ of $\mathrm{OH}^{-}$anions were reacted), suggesting that most of the $\mathrm{OH}^{-}$ions were bonded to the gel structure as silanol groups, as shown in the TGA studies. Finally, a significant decrease in electrical conductivity values was also observed in the period from 28 to 270 days. In this case, the lowest value was found for the S3-75/25 mixture, suggesting that for long curing times, the reactivity of fly ash contributed strongly to the reaction.

The compressive strength of mortars cured at $65{ }^{\circ} \mathrm{C}$ are shown in Fig. $11 \mathrm{a}$, whereas the results for mortars cured at $20^{\circ} \mathrm{C}$ are shown in Fig. $11 \mathrm{~b}$. For the mortars cured at $65^{\circ} \mathrm{C}$, after 3 days of curing, the mixture with the highest compressive strength was the S3-75/25 (33.5 MPa), followed by S3-50/50 (27.0 MPa) and S3-25/75 (21.6 MPa). After 7 days of curing, the compressive strength trend was similar, where the mixture with the highest percentage of FA yielded the greatest strength, reaching 
Table 5

TGA results from Section 2 studies after 7, 28 and 270 days of curing at room temperature $\left(20^{\circ} \mathrm{C}\right)$ for pastes prepared with different FA/SCBA ratios.

\begin{tabular}{|c|c|c|c|c|c|c|c|c|c|c|c|c|}
\hline \multirow[t]{2}{*}{ Mixture } & \multicolumn{4}{|c|}{ Total mass loss (\%) } & \multicolumn{4}{|c|}{ Peak temperature $\left({ }^{\circ} \mathrm{C}\right)$} & \multicolumn{4}{|c|}{$\tau\left(L_{35-200} / L_{200-550}\right)^{\mathrm{a}}$} \\
\hline & 7 days & 28 days & 90 days & 270 days & 7 days & 28 days & 90 days & 270 days & 7 days & 28 days & 90 days & 270 days \\
\hline S3-75/25 & 11.63 & 11.78 & 10.28 & 9.86 & 131 & 138 & 143 & 160 & 4.05 & 2.40 & 1.00 & 0.58 \\
\hline S3-50/50 & 10.24 & 10.94 & 11.30 & 9.76 & 142 & 135 & 136 & 160 & 2.72 & 2.09 & 1.31 & 0.57 \\
\hline S3-25/75 & 11.31 & 12.00 & 10.13 & 9.85 & 131 & 131 & 136 & 159 & 2.67 & 2.38 & 1.15 & 0.59 \\
\hline
\end{tabular}

${ }^{\text {a }} L_{35-200}$ is the mass loss in the temperature range of $35-200{ }^{\circ} \mathrm{C}$, whereas $L_{200-550}$ is the mass loss in the range of $200-550{ }^{\circ} \mathrm{C}$.

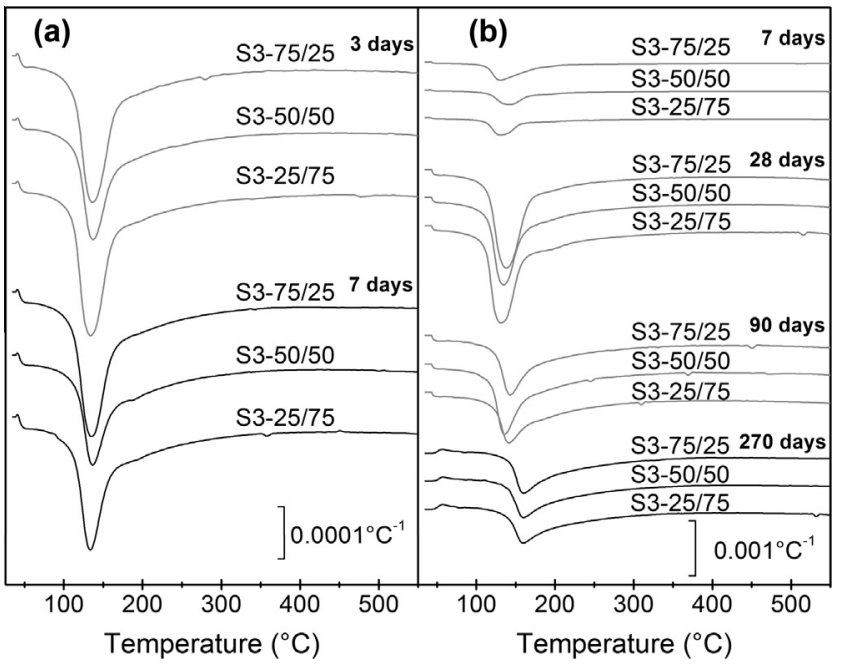

Fig. 7. DTG curves of alkali-activated binders prepared with different FA/SCBA rations after: (a) 3 and 7 days of curing at $65^{\circ} \mathrm{C}$; and (b) 7, 28, 90 and 270 days of curing at room temperature $\left(20^{\circ} \mathrm{C}\right)$.

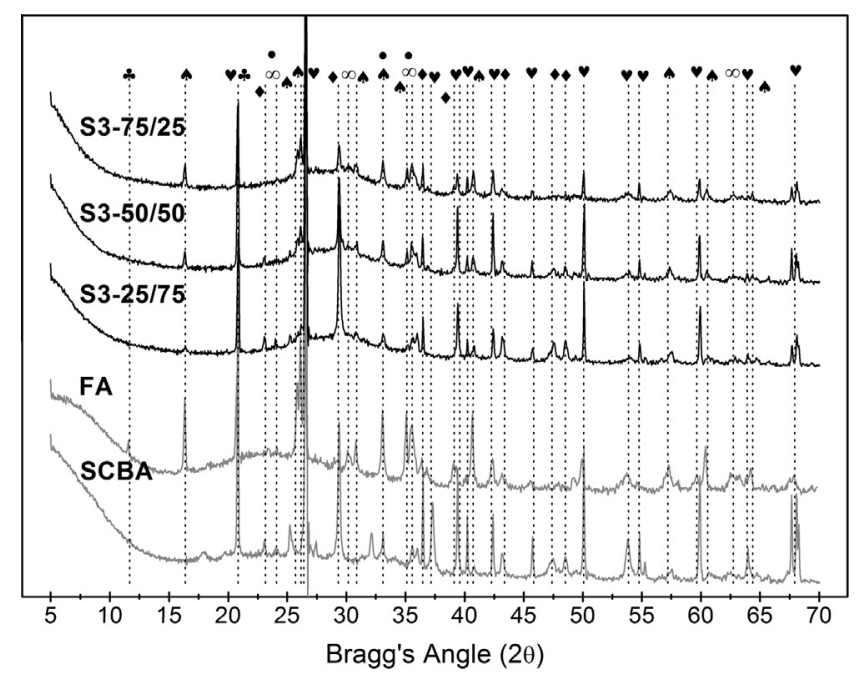

Fig. 8. XRD pattern of alkali-activated binders prepared with different FA/SCBA ratios after 270 days of curing at room temperature $\left(20^{\circ} \mathrm{C}\right)$, (Key: $\bullet$ : Quartz; $\bullet$ : Calcite; $\boldsymbol{\text { a: }}$ Gypsum; $\mathbf{\text { } : ~ M u l l i t e ; ~ \bullet : ~ H e m a t i t e ; ~} \infty$ : Magnetite).

36.4 MPa. Also, the other two mixtures showed increased strength with curing time: $33.1 \mathrm{MPa}$ for S3-50/50 and $23.4 \mathrm{MPa}$ for S3-25/75. These changes in strength were correlated to the behavior observed in the TGA, pH and electrical conductivity measurements. Thus, the decrease in $\tau$ values and the reduction in electrical conductivity were both related to the progress of the polymerization reaction, which enhanced the compressive strength. For mortars cured at room temperature, the compressive strength increased with curing age for all mixtures. After 7 days of

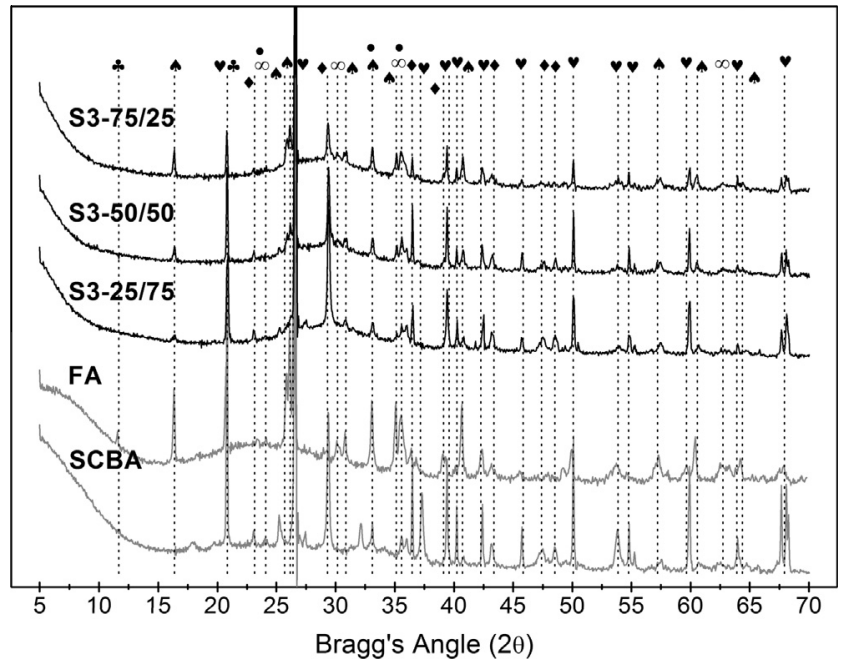

Fig. 9. XRD pattern of alkali-activated binders prepared with different FA/SCBA ratios after 7 days of curing at $65{ }^{\circ} \mathrm{C}$ (Key: $\bullet$ : Quartz; $\bullet$ : Calcite; $\boldsymbol{中}:$ Gypsum; $\mathbf{\phi}$ Mullite; •: Hematite; $\infty$ : Magnetite).

curing, S3-25/75 (11.3 MPa) presented the highest value of compressive strength compared to S3-75/25 (3.7 MPa) and S3-50/50 (7.3 MPa). This result has great interest from the point of view related to the role of SCBA in these mixtures. Thus, the presence of SCBA particles produced an early reaction under the studied conditions, demonstrating the relevant presence of this mineral admixture for yielding good strength behavior in the first 7 days. Apparently, the reactivity of SCBA at early ages is decisive in the mechanical development of FA/SCBA mixtures: the contribution of FA to strength development was delayed with respect to the contribution from SCBA. However, the presence of FA particles was necessary because they supply reactive alumina to produce the cementing gel. In fact, $100 \%$ SCBA activated samples did not harden, demonstrating the critical role of FA particles in the mixture. After 28 days of curing, a high gain in compressive strength was shown for S3-75/25 (32.1 MPa) and S3-50/50 (27.7 MPa), if compared to the compressive strength development found for S3-25/75 (23.1 MPa). This late compressive strength gain was due the characteristic FA reactivity as a binder with a slow reaction rate $[18,43]$. After 270 days of curing, an approximately increase of $20 \%$ in compressive strength was noted for all mixtures, reaching 40.3, 35.2 and 28.0 MPa for S3-75/25, S3-50/50 and S3-25/75, respectively. Trends observed in the mechanical properties with long curing times can be correlated to the results of the $\mathrm{pH} /$ electrical conductivity and thermogravimetric measurements. So, a total mass loss from 28 days to 270 days was observed; however, mechanical strength increased. This enhancement in the mechanical properties could be attributed to the change in the nature of the combined water in the gel, as relatively more water was bonded in the gel as silanol and aluminol groups $\left(L_{200-550}\right)$, shown as a decrease in $\tau$ values and better strength of the matrix. Additionally, a significant decrease in electrical conductivity and 


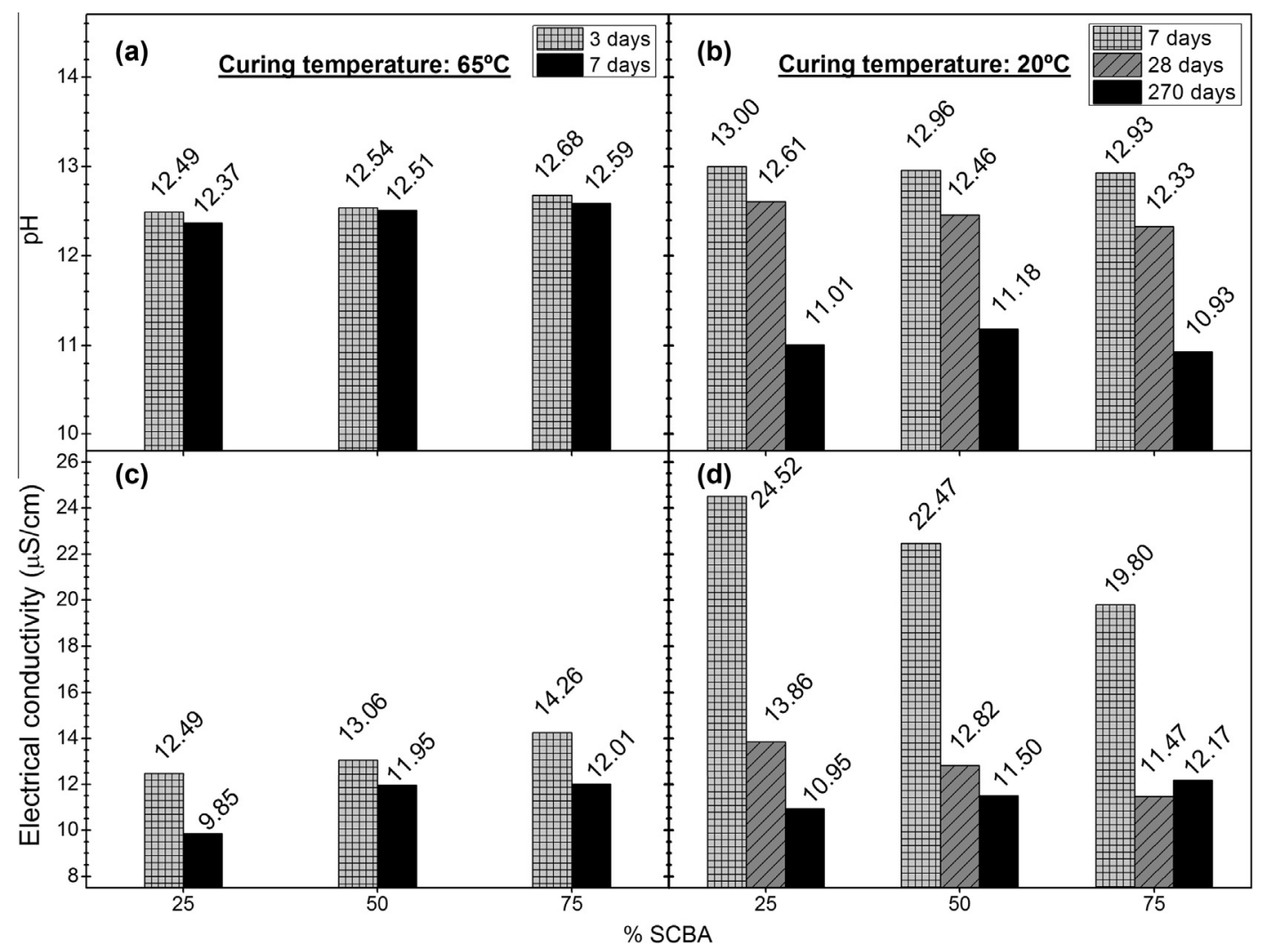

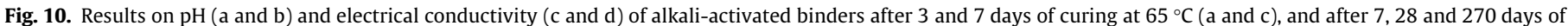
curing at room temperature $\left(20^{\circ} \mathrm{C}\right)(\mathrm{b}$ and d) for pastes prepared with different FA/SCBA ratios.

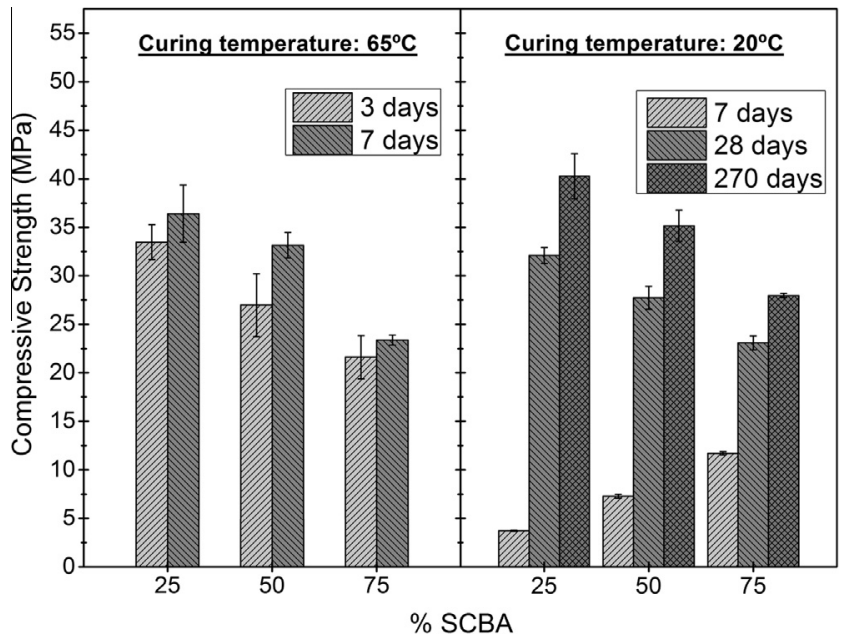

Fig. 11. Compressive strength of alkali-activated binders with different FA/SCBA proportions after: (a) 3 and 7 days of curing at $65^{\circ} \mathrm{C}$; and (b) 7, 28 and 270 days of curing at room temperature $\left(20^{\circ} \mathrm{C}\right)$.

especially pH values was observed for the same interval of curing time, which is in good agreement with the compressive strength behavior. When the mortars cured at room temperature were compared to those cured at $65^{\circ} \mathrm{C}$, it was noted that the specimens cured at the highest temperature for 7 days presented $90 \%$ of the compressive strength of the mortars cured at room temperature for 270 days. This difference could be attributed to the different nature of the combined water in the gel structure, as can be seen in the $\tau$ values for both curing conditions (see Tables 4 and 5).

MIP studies were carried out on the mortars after 3 days of curing at $65^{\circ} \mathrm{C}$ (Table 6) and after 270 days at room temperature
(Table 7), and for pastes, after 270 days of curing at room temperature (Table 8). First, for mortars cured for 3 days at $65^{\circ} \mathrm{C}$, a higher amount of SCBA in the mixture caused an increase in total porosity. S3-75/25 showed the lowest pore volume for macropores ( $>1 \mu \mathrm{m})$ and for capillary pores $(1 \mu \mathrm{m}-10 \mathrm{~nm})$, which agrees with the mechanical properties. The volume of mesopores $(<10 \mathrm{~nm})$ was very low for all tested mixtures. In addition, in terms of $\mathrm{Hg}$ retained, S3-50/50 presented the highest value, followed by S3-75/25 and S3-25/75, suggesting the former presented a higher degree of tortuosity.

For mortars cured after 270 days at room temperature, total porosity values were similar to those found in samples cured at $65^{\circ} \mathrm{C}$. S3-50/50 and S3-25/75 showed lower slightly values of total porosity, whereas S3-75/25 showed higher porosity. The Hg retained in samples cured at room temperature presented lower values than samples cured at $65^{\circ} \mathrm{C}$, suggesting that tortuosity was greater with an increase in curing temperature. In samples cured at room temperature, the pore volume related to macropores was significantly lower than that found at $65{ }^{\circ} \mathrm{C}$; the development of the matrix at the lowest curing temperature yielded a better distribution of the formed gel. This behavior produced an increase in the smallest capillary pores (50-10 nm). The mesopore volume did not vary with respect to the $65^{\circ} \mathrm{C}$ curing condition. It is likely that better mechanical development for samples cured at room temperature could be attributed to changes in macropores and capillary pores.

Comparing the pore volume distribution between paste and mortar samples cured at room temperature, relative pore volume values were calculated and are depicted in Fig. 12. The influence of the sand on the relative pore volume distribution can be seen in the volume percentage for the largest pores; thus, the volume percentage of macropores in mortars was in the range of $18-21 \%$, whereas for pastes, it was reduced to $5-9 \%$. The same trend was observed for the largest capillary pores $(50 \mathrm{~nm}-1 \mu \mathrm{m})$. Both for 
Table 6

MIP results of mortars prepared with different FA/SCBA ratios and cured after 3 days at $65^{\circ} \mathrm{C}$.

\begin{tabular}{|c|c|c|c|c|c|c|c|c|c|}
\hline \multirow[t]{2}{*}{ Mixtures } & \multirow[t]{2}{*}{ Total porosity (\%) } & \multirow[t]{2}{*}{ Total pore area $\left(\mathrm{m}^{2} / \mathrm{g}\right)$} & \multicolumn{2}{|c|}{ Median pore diameter } & \multicolumn{4}{|c|}{ Volume (mL of $\mathrm{Hg} / \mathrm{g}$ of mortar) } & \multirow[t]{2}{*}{$\mathrm{Hg}$ retained $(\%)$} \\
\hline & & & Volume (nm) & Area $(\mathrm{nm})$ & $>1 \mu \mathrm{m}$ & $1 \mu \mathrm{m}-50 \mathrm{~nm}$ & $50-10 \mathrm{~nm}$ & $<10 \mathrm{~nm}$ & \\
\hline S3-75/25 & 16.98 & 16.25 & 17.3 & 12.1 & 0.0175 & 0.0078 & 0.0376 & 0.0059 & 53.58 \\
\hline S3-50/50 & 20.12 & 16.99 & 17.6 & 13.1 & 0.0266 & 0.0101 & 0.0467 & 0.0032 & 60.80 \\
\hline S3-25/75 & 21.03 & 12.62 & 104.6 & 14.6 & 0.0424 & 0.0109 & 0.0420 & 0.0010 & 56.66 \\
\hline
\end{tabular}

Table 7

MIP results of mortars prepared with different FA/SCBA ratios and cured after 270 days at room temperature $\left(20^{\circ} \mathrm{C}\right)$.

\begin{tabular}{|c|c|c|c|c|c|c|c|c|c|}
\hline \multirow[t]{2}{*}{ Mixtures } & \multirow[t]{2}{*}{ Total porosity (\%) } & \multirow[t]{2}{*}{ Total pore area $\left(\mathrm{m}^{2} / \mathrm{g}\right)$} & \multicolumn{2}{|c|}{$\underline{\text { Median pore diameter }}$} & \multicolumn{4}{|c|}{ Volume (mL of $\mathrm{Hg} / \mathrm{g}$ of mortars) } & \multirow[t]{2}{*}{$\mathrm{Hg}$ retained $(\%)$} \\
\hline & & & Volume (nm) & Area $(\mathrm{nm})$ & $>1 \mu \mathrm{m}$ & $1 \mu \mathrm{m}-50 \mathrm{~nm}$ & $50-10 \mathrm{~nm}$ & $<10 \mathrm{~nm}$ & \\
\hline S3-75/25 & 19.26 & 21.62 & 13.8 & 11.1 & 0.0152 & 0.0099 & 0.0377 & 0.0094 & 51.58 \\
\hline S3-50/50 & 18.10 & 16.77 & 16.7 & 13.9 & 0.0151 & 0.0078 & 0.0515 & 0.0021 & 50.20 \\
\hline S3-25/75 & 20.50 & 15.14 & 21.0 & 18.6 & 0.0173 & 0.0068 & 0.0683 & 0.0001 & 47.91 \\
\hline
\end{tabular}

Table 8

MIP results of pastes prepared with different FA/SCBA ratios and cured after 270 days at room temperature $\left(20^{\circ} \mathrm{C}\right)$.

\begin{tabular}{|c|c|c|c|c|c|c|c|c|c|}
\hline \multirow[t]{2}{*}{ Mixtures } & \multirow[t]{2}{*}{ Total porosity (\%) } & \multirow[t]{2}{*}{ Total pore area $\left(\mathrm{m}^{2} / \mathrm{g}\right)$} & \multicolumn{2}{|c|}{ Median pore diameter } & \multicolumn{4}{|c|}{ Volume (mL of $\mathrm{Hg} / \mathrm{g}$ of paste) } & \multirow[t]{2}{*}{$\mathrm{Hg}$ retained $(\%)$} \\
\hline & & & Volume (nm) & Area $(\mathrm{nm})$ & $>1 \mu \mathrm{m}$ & $1 \mu \mathrm{m}-50 \mathrm{~nm}$ & $50-10 \mathrm{~nm}$ & $<10 \mathrm{~nm}$ & \\
\hline S3-75/25 & 41.38 & 119.54 & 8.6 & 8.1 & 0.0154 & 0.0060 & 0.0352 & 0.1674 & 54.22 \\
\hline S3-50/50 & 43.56 & 101.53 & 10.8 & 10.2 & 0.0148 & 0.0053 & 0.1079 & 0.0393 & 53.42 \\
\hline S3-25/75 & 42.52 & 73.07 & 15.1 & 14.8 & 0.0160 & 0.0067 & 0.2478 & 0.0055 & 56.45 \\
\hline
\end{tabular}

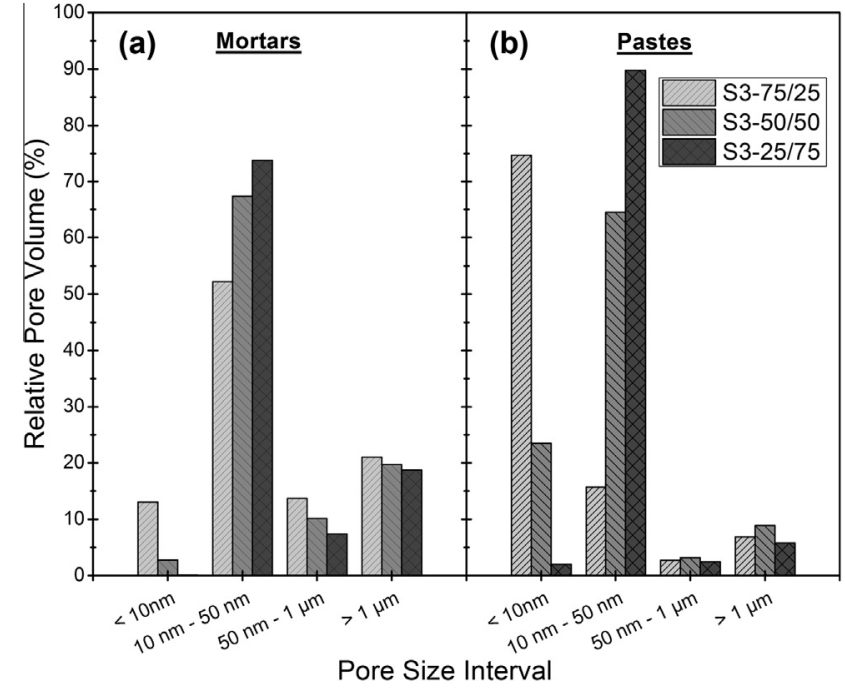

Fig. 12. Comparison of relative pore volume distribution between pastes and mortars with different FA/SCBA ratios cured for 270 days at room temperature $\left(20^{\circ} \mathrm{C}\right)$ : (a) mortars; (b) pastes.

pastes and mortars, samples with the highest percentage of fly ash (S3-75/25) presented the best behavior in terms of relative porosity. Therefore, the relative pore volume for the smallest capillary pores $(10-50 \mathrm{~nm})$ was lower for the S3-75/25 mixture and the relative pore volume increased with the SCBA content. On the contrary, the highest relative mesopore volume $(<10 \mathrm{~nm})$ was found for the $\mathrm{S} 3-75 / 25$ mixture. In the case of pastes, the relative pore volume for $\mathrm{S} 3-75 / 25$ was $75 \%$. This behavior suggests that the presence of a high percentage of fly ash provides good pore refinement at a curing temperature of $20^{\circ} \mathrm{C}$.

\section{Conclusions}

Alkali-activated binders can be obtained by blending fly ash and sugarcane bagasse ash (FA/SCBA systems). The influence of the
$\mathrm{SiO}_{2} / \mathrm{K}_{2} \mathrm{O}$ molar ratio in the activating solution was decisive in terms of compressive strength and microstructure development at a curing temperature of $65^{\circ} \mathrm{C}$. Also the effect of the FA/SCBA ratio has an important role. From the microstructural and mechanical strength studies on pastes and mortars cured at room temperature and $65^{\circ} \mathrm{C}$, the $\mathrm{FA} / \mathrm{SCBA}$ proportion of $75 / 25$ presented the best results for alkali-activated mixtures using a solution with $0.75 \mathrm{SiO}_{2} / \mathrm{K}_{2} \mathrm{O}$ molar ratio. The thermogravimetric studies, as well as $\mathrm{pH}$ and electrical conductivity measurements agreed with the evolution of mechanical strength. The change in the nature of the water bonded to the gel was defined from thermogravimetric data by a new parameter $(\tau)$ proposed as the ratio of the mass losses in the ranges $35-200{ }^{\circ} \mathrm{C}\left(L_{35-200}\right)$ and $200-550{ }^{\circ} \mathrm{C}\left(L_{200-550}\right)$.

\section{Acknowledgments}

The authors would like to thank the Ministerio de Educación, Cultura y Deporte of Spain (Cooperación Interuniversitaria program with Brazil, Project PHB-2011-0016-PC), CAPES Brazil (Project CAPES/DGU No. 266/12) and CNPq (process $\mathrm{n}^{\circ}$ 401724/2013-1).

\section{References}

[1] Sharp JH, Gartner EM, Macphee DE. Novel cement system (sustainability) Session 2 of the Fred Glasser cement science symposium. Adv Cem Res 2010;22(4):195-202.

[2] Palomo A, Grutzeck MW, Blanco MT. Alkali-activated fly ashes a cement for the future. Cem Concr Res 1999;29:1323-9.

[3] Duxson P, Fernández-Jiménez A, Provis JL, Lukey GC, Palomo A, van Deventer JSJ. Geopolymer technology: the current state of the art. J Mater Sci 2007:42:2917-33.

[4] Provis JL, van Deventer JSJ. Geopolymers: structure, processing, properties and industrial applications. 1st ed. Oxford: Woodhead Publishing Limited; 2009.

[5] Mehta PK, Monteiro PJM. Concrete: microstructure, properties, and materials. 3rd ed. New York: McGraw-Hill; 2006.

[6] Davidovits J. Environmentally driven geopolymer cement applications. Geopolymer international conference; 2002.

[7] McLellan B, Williams R, Lay J, Van Riessen A, Corder G. Costs and carbon emissions for geopolymer pastes in comparison to ordinary Portland cement. J Clean Prod 2011;19:1080-90. 
[8] Davidovits J. Geopolymer chemistry and applications. 3rd ed. France: Institut Géopolymère; 2001.

[9] Tashima MM, Akasaki JL, Melges JLP, Soriano L, Monzó J, Payá J, et al. Alkali activated materials based on fluid catalytic cracking catalyst residue (FCC): Influence of $\mathrm{SiO}_{2} / \mathrm{Na}_{2} \mathrm{O}$ and $\mathrm{H}_{2} \mathrm{O} / \mathrm{FCC}$ ratio on mechanical strength and microstructure. Fuel 2013;108:833-9.

[10] Fernández-Jimenez A, de la Torre AG, Palomo A, López-Olmo G, Alonso MM, Aranda MAG. Quantitative determination of phases in the alkali activation of fly ash. Part I. Potential ash reactivity. Fuel 2006;85:625-34.

[11] Guo X, Shi H, Dick WA. Compressive strength and microstructural characteristics of class C fly ash geopolymer. Cem Concr Compos 2010;32:142-7.

[12] Shi C, Krivenko PV, Roy D. Alkali-activated cements and concretes. 1st ed. Taylor \& Francis; 2006.

[13] Fillenwart BA, Sastry SML. Development of a predictive optimization model for the compressive strength of sodium activated fly ash based geopolymer pastes. Fuel 2015;147:141-6.

[14] Tchakoute HK, Ruscher CH, Djobo JNY, Kenn BBD, Njopwouo D. Influence of gibbsite and quartz in kaolin on the properties of metakaolin-based geopolymer cements. Appl Clay Sci 2015;107:188-94.

[15] Kovtun M, Kearsley EP, Shekhovtsova J. Chemical acceleration of a neutral granulated blast-furnace slag activated by sodium carbonate. Cem Concr Res 2015;72:1-9.

[16] Rattanasak U, Chindaprasirt P, Suwanvitaya P. Development of high volume rice husk ash alumino silicate composites. Int J Mineral Metall Mater 2010;17:654-9.

[17] Xu H, Gong W, Syltebo L, Izzo K, Lutze W, Pegg IL. Effect of blast furnace slag grades on fly ash based geopolymer waste forms. Fuel 2014;133:332-40.

[18] Zhang Z, Wang H, Zhu Y, Reid A, Provis JL, Bullen F. Using fly ash to partially substitute metakaolin in geopolymer synthesis. App Clay Sci 2014;8889:194-201.

[19] Zhang M, El-Korchi T, Zhang G, Liang J, Tao M. Synthesis factors affecting mechanical properties, microstructure, and chemical composition of red mudfly ash based geopolymers. Fuel 2014;134:315-25.

[20] Joshi RC, Lothia RP. Fly ash in concrete: production, properties and uses. 1st ed. Amsterdam: Gordon and Breach Science Publishers; 1997.

[21] Celik K, Meral C, Mancio M, Mehta PM, Monteiro PJM. A comparative study of self-consolidating concretes incorporating high-volume natural pozzolan or high-volume fly ash. Constr Build Mater 2014;67:14-9.

[22] Duxon P, Fernández-Jiménez A, Provis JL, Lukey GC, Palomo A, van Deventer ISJ. Geopolymer technology: the current state of the art. J Mater Sci 2007;42:2917-33.

[23] Sugarcane production. UNICA - União da Indústria de Cana-de-Açúcar Website. <http://www.unicadata.com.br/index.php?idioma=2> (accessed: 20/ 09/2015).

[24] Hugot E. Handbook of cane sugar engineering. 3rd ed. Amsterdam: Elsevier Science Publishers; 1986.

[25] Hofsetz K, Silva MA. Brazilian sugarcane bagasse: energy and non-energy consumption. Biomass Bioenergy 2012;46:564-73.

[26] Souza AE, Teixeira SR, Santos GTA, Costa FB, Longo E. Reuse of sugarcane bagasse ash (SCBA) to produce ceramic materials. J Environ Manage 2011;92:2774-80.
[27] Cordeiro GC, Toledo Filho RD, Tavares LM, Fairbairn EMR. Ultrafine grinding of sugar cane bagasse ash for application as pozzolanic admixture in concrete. Cem Concr Res 2009;39:110-5.

[28] Castaldelli VN, Akasaki JL, Melges JLP, Tashima MM, Soriano L, Borrachero MV, et al. Use of slag/sugar cane bagasse ash (SCBA) blends in the production of alkali-activated materials. Materials 2013;6:3108-27.

[29] Tippayasan C, Boonsalee S, Sajjavanich S, Ponzoni C, Kamseu E, Chaysuwan D. Geopolymer development by powder of metakaolin and wastes in Thailand. Adv Sci Technol 2010;69:63-8.

[30] Rattanasak U, Chindaprasirt P. Influence of $\mathrm{NaOH}$ solution on the synthesis of fly ash geopolymer. Miner Eng 2009;22:1073-8.

[31] Riahi S, Nazari A, Zaare D, Khalaj G, Bohlooli H, Kaykha MM. Compressive strength of ash-based geopolymers at early ages designed by Taguchi method. Mater Des 2012;37:443-9.

[32] Payá J, Monzó J, Borrachero MV, Díaz-Pinzón L, Ordóñez LM. Sugar-cane bagasse ash (SCBA): studies on its properties for reusing in concrete production. J Chem Technol Biotechnol 2002;77:321-5.

[33] AENOR-Asociación Española de Normalización y Certificación. Methods of testing cement - part 1: Determination of strength; UNE 196-1:2005; AENOR: Madrid, Spain; 2005.

[34] Ozer I, Soyer-Uzun S. Relations between the structural characteristics and compressive strength in metakaolin based geopolymers with different molar Si/Al ratios. Ceram Int 2015;41:10192-8.

[35] Ryu GS, Lee YB, Koh KT, Chung YS. The mechanical properties of fly ash-based geopolymer concrete with alkaline activators. Constr Build Mater 2013;47:409-18.

[36] Bernal SA, van Deventer JSJ, Provis JL. What happens to 5-year old metakaolin geopolymers? The effect of the alkali cation. In: 1st International conference on calcined clays for sustainable concrete 2015; Lausanne, Switzerland.

[37] Moraes JCB, Akasaki JL, Melges JLP, Monzó J, Borrachero MV, Soriano L, et al. Assessment of sugar cane straw ash (SCSA) as pozzolanic material in blended Portland cement: Microstructural characterization of pastes and mechanical strength of mortars. Constr Build Mater 2015;94:670-7.

[38] Provis JL, Lukey GC, van Deventer JSJ. Do geopolymers actually contain nanocrystalline zeolites? A reexamination of existing results. Chem Mater 2005; 17:3075-85.

[39] Mellado A, Catalán C, Bouzón N, Borrachero MV, Monzó JM, Payá J. Carbon footprint of geopolymeric mortar: study of the contribution of the alkaline activating solution and assessment of an alternative route. RSC Adv 2014:4:23846-52.

[40] Frías M, Villar E, Savastano H. Brazilian sugar cane bagasse ashes from the cogeneration industry as active pozzolans for cement manufacture. Cem Concre Res 2011;33:490-6.

[41] Ress CA, Provis JL, Lukey GC, van Deventer JSJ. In situ ATR-FTIR study of the early stages of fly ash geopolymer gel formation. Langmuir 2007;23: 9076-82.

[42] Saidi N, Samet B, Baklouti S. Effect of composition on structure and mechanica properties of metakaolin based PSS-geopolymer. Int J Mater Sci 2013;3 (4):145-51.

[43] Ahmaruzzaman M. A review on the utilization of fly ash. Prog Energy Combust 2010;36:327-63. 